\title{
Tracking COVID-19 Decease Through Rolling Conditional Variance
}

\author{
Cesar Gurrola-Ríos ${ }^{1} \&$ Ana Lorena Jiménez-Preciado ${ }^{2}$ \\ ${ }^{1}$ Universidad Juárez del Estado de Durango, Durango, México \\ ${ }^{2}$ Escuela Superior de Economía, Instituto Politécnico Nacional, Ciudad de México, México \\ Correspondence: Ana Lorena Jiménez-Preciado, Superior de Economía, Instituto Politécnico Nacional, Ciudad de \\ México, México, Plan de Agua Prieta 66. Col. Plutarco Elías Calles. CP 11350, Miguel Hidalgo, Ciudad de México. \\ E-mail: ajimenezp@ipn.mx
}

Received: November 2, 2021

Accepted: December 1, 2021

Online Published: December 16, 2021

doi:10.5430/rwe.v12n4p111

URL: https://doi.org/10.5430/rwe.v12n4p111

The project has been elaborated in the exercise of sabbatical year UJED. The article is supported by the project SIP 20210401.

\begin{abstract}
The effects of COVID-19 have been devastating globally. However, countries have essential asymmetries regarding the disease spread dynamics and the respective mortality rates. In addition to containment strategies and boosting growth and economic development in the face of the COVID-19 pandemic, society calls for solutions that allow the development of vaccines, treatments for the disease, and especially, indicators or early warnings that anticipate the evolution of new infections and deaths. This research aims to track the total deaths caused by COVID-19 in the most affected countries by the pandemics after the approval, distribution, and implementation of vaccines from 2021. We proposed an Autoregressive Integrated Moving Average (ARIMA) specification as a first adjustment. Subsequently, we estimate the conditional variance of total deaths from an Exponential Generalized Autoregressive Conditional Heteroscedasticity (EGARCH). Finally, we compute a rolling density backtesting within a 7-day rolling window to demonstrate the robustness estimation for COVID-19 mortality. The work's main contribution lies in exhibiting a tracking indicator for volatility and COVID-19 direction, including a weekly window to observe its evolution.
\end{abstract}

Keywords: COVID-19 tracking, rolling conditional variance, ARIMA, EGARCH, forecasting

JEL Classification: C53, F69, I10.

\section{Introduction}

The health crisis caused by the SARS-COV-2 coronavirus revealed the degree of vulnerability of homo sapiens and their health, social, economic, and political institutions. Empirical evidence indicates several costs associated with the COVID-19 besides nearly five million deaths and 240 million infections. For example, reduction in world economic activity, abrupt falls in international financial markets, job losses, business closings, decrease in patterns of social mobility, a significant increase in domestic violence cases, and other disorders of the human psyche as a response to confinement measures. Likewise, there is an increase in school dropout and backwardness levels before adopting new paradigms and educational strategies and the lack of information technology infrastructure in many regions of the planet, to mention a few aspects (Ekinci, 2021).

The impact of the COVID-19 pandemic also showed the lack of attention in health systems infrastructure, insufficient resources allocated to research and development on bacteriological issues, and the development of vaccines. Likewise, the adverse effects of the coronavirus seem to reflect the progressive strengthening of globalization and financial market integration, causing diverse economic and public health damage.

The international scientific community analyses the causes and effects of the SARS-COV-2 virus from a holistic perspective to better understand the spread of the pandemic, containment techniques, and the design of strategies to face its multiple harmful effects. Thus, forecasting the evolution of the COVID-19 disease through new infections and deaths is an urgent and essential activity (Sahai, Rath, Sood, \& Singh, 2020). This work adds to the efforts that have addressed the causes, consequences, and implications of the COVID-19 pandemic on different areas of human endeavor by modeling the behavior of daily deaths in the most affected countries after approval, distribution, and implementation of vaccines, from April 1, 2020, to September 20, 2021. Starting from an Autoregressive Integrated Moving Average (ARIMA) specification, we estimate the conditional variance of total deaths using an Exponential Generalized Autoregressive Conditional Heteroscedasticity model (EGARCH). Finally, we calculated a rolling 
backtesting within a 7-day rolling window to demonstrate the robustness estimate of COVID-19 mortality. The work's main contribution is to show a volatility monitoring indicator and COVID-19 direction, including a weekly window to observe its evolution. Our research results can be used to assist in the design of early warnings that allow taking preventive, health, and economic measures, in the face of unforeseen shocks, such as the COVID-19 pandemic.

The second section discusses relevant literature to get an overview of factors that, from the financial sphere, have contributed to the transmission of effects between different economies; several consequences of the pandemic are discussed along with recent proposals to model the monitoring of its deadly effects. Sections three and four offer the methodological aspects and the discussion of the results obtained, respectively. Finally, section five presents the conclusions and recommendations of the study.

\section{Literature Review}

\subsection{SARS-COV-2 Effects}

The health crisis caused by the COVID-19 pandemic has had essential consequences on world dynamics. Even though its effects have been compared with, until then, the most significant health crisis documented in the 20th century: the 1918 Spanish H1N1 influenza pandemic. The COVID-19 crisis begins at the end of 2020 as a public health problem: a new coronavirus, with high levels of contagion and mortality, identified as SARS-COV-2, in Wuhan, capital of the Hubei province in China, and that quickly spread to practically every country in the world (Sahai et al., 2020). In response, the World Health Organization (WHO) was forced to decree the pandemic in March 2001. As with the 1918 crisis, the one caused by COVID-19 has also triggered countless studies and investigations in the more diverse areas of knowledge (De Salles, 2021).

There are multiple similarities by comparing the effects of the 1918 H1N1 versus the current COVID-19 health crises. In the first of them, some acute health effects were identified, such as hospital costs, lost workdays, drug costs, and, of course, the number of deaths. On the other hand, within the economic effects, the reorientation of public spending, the increase in resources on health and economic aid to vulnerable sectors, the decrease in fiscal income, and the corresponding fiscal deficit of the government stand out in addition to multiplier effects, economic and significant changes in the behavior pattern of aggregate consumption, to mention just a few aspects (Mackellar, 2007). The COVID-19 pandemic has directly affected social and economic life in practically all the world's countries, negatively affecting financial markets, economic agents' expectations through the money, exchange, credit, and capital markets and their corresponding effect on financing, saving, and investment (De Salles, 2021). The advance of the health ravages of the COVID-19 pandemic, particularly the number of deaths, decreases confidence in financial markets in the face of expectations of prolonged lockdowns and a slow recovery in economic growth (Daehler, Aizenman, \& Jinjarak, 2021).

The COVID-19 crisis has also caused significant damage to supply chains, loss of employment, increased poverty levels, social unrest, and even, it has had significant effects on education and learning, among other manifestations of the human psyche (Ekinci, 2021). Regarding economic impacts, the COVID-19 pandemic triggered falls in global capital markets value of approximately $30 \%$, because of the high levels of contagion and mortality of the SARS-COV-2 virus, as well as to the measures of confinement and reduction of economic activity (Ali, Alam, \& Rizvi, 2020).

The COVID-19 pandemic had significantly negative impacts on emerging economies; besides, the potential to unleash the greatest crisis in such economies can transmit harmful effects to their developed counterparts (Cakmakli, Demiralp, Kalemli-Ozcan, Yesiltas, \& Yildirim, 2020) According to the WHO, table 1 offers a list of the countries with the most deaths from SARS-COV-2. It is important to note that six of these countries (86\%) correspond to emerging economies.

Table 1. Countries with the highest deaths number by COVID-19

\begin{tabular}{llrlrr}
\hline \multicolumn{1}{c}{ Country } & Deaths & \multicolumn{1}{c}{ Confirm cases } & Country & \multicolumn{1}{c}{ Deaths } & \multicolumn{1}{c}{ Confirm cases } \\
\hline USA & 657114 & 41066110 & Italia & 130027 & 4613214 \\
Brazil & 587066 & 21006424 & Colombia & 125687 & 4931563 \\
India & 443497 & 33316755 & Iran & 115167 & 5340656 \\
Mexico & 267969 & 3516043 France & 113681 & 6710718 \\
Peru & 198799 & 2161358 Argentina & 113640 & 5226831 \\
Russia & 195041 & 7194926 Germany & 92769 & 4101931 \\
Indonesia & 139682 & 4178164 & Spain & 85548 & 4918526 \\
United Kingdom & 134446 & 7282814 & & \\
\hline
\end{tabular}


In the months that followed the declaration of the COVID-19 pandemic, emerging countries began to show symptoms of economic-financial deterioration due to the increase in the cost of external financing, significant reductions in commodity prices, depreciation of currencies, the collapse of demand, capital withdrawals, among other aspects (Note 1). In response, the governments of these economies, as in some cases in their advanced counterparts, increased their domestic debt through unconventional policies that allowed them fiscal resources to face the challenge imposed by the pandemic (Rodríguez, Gurrola, \& López, 2021). Notwithstanding, the ravages of the COVID-19 pandemic were more significant in Latin American; a third of the countries in table 1 belong to this region where their economies are more susceptible to receiving the effects of a global crisis, such as that caused by the SARS-COV-2 virus (De Salles, 2021).

Experts on the subject of pandemics have pointed out other alarming aspects to consider about the SARS-COV-2 virus. On the one hand, the pandemic evolution suggests that the entire world population will face the virus, whether vaccinated or not. On the other, the appearance of various outbreaks is inevitable, so it will probably become a global endemic virus. In a recent study, (Ramírez \& Jiménez, 2021) studied the evolution of the COVID-19 pandemic in a group of advanced and emerging economies concerning their economic growth. Using dynamic modeling and machine learning techniques, the authors find that the cyclical trajectory of CODID-19 suggests its duration may be longer than expected according to official reports up to 9 years unless there are significant measures regarding the implementation of vaccines or the strengthening of health policies.

\subsection{Modelling COVID-19 Deaths' Behavior}

The effects of the COVID-19 pandemic triggered the scientific community mobilization for design diagnostic and mitigation strategies and the search and development of treatments and vaccines. Part of the community's efforts focused on proposals to forecast the evolution and effects of the pandemic in various aspects and phenomena. It is highlighted that in the area known as biosurveillance, in the last 20 years, interest in prospective studies on infectious disease outbreaks has increased (Sahai et al., 2020).

Although the pandemic was initially a public health phenomenon, it can also be characterized as an unforeseen disturbance or shock through time series analysis The Auto-Regressive Integrated Moving Average (ARIMA) models are among the most popular specifications for making time-series forecasts (Note 2). Although such models became popular from applications in economics and finance, they have been widely used to anticipate infectious outbreaks thanks to their simplicity, systematic structure, and, above all, the level of effectiveness of its forecasts (Wang et al., 2018). Some recent examples of ARIMA models for forecasting the spread of the COVID-19 pandemic are found in Sahai et al., (2020) and (Ceylan, 2020). The first one uses an ARIMA model in the five countries with the highest number of infections: United States, Brazil, India, Russia, and Spain; the authors found acceptable results at 18 days, under the criteria of the mean absolute deviation (MAD) and the percentage of mean absolute error (MAPE). Ceylan (2020) uses the ARIMA methodology in Italy, Spain, and France, obtaining a good level of forecast adjustment under the minimum MAPE criterion.

Shinde et al., (2020) offer an extensive literature review on forecasting tools, impact, and control measures of the COVID-19 pandemic. After analyzing the available evidence, which they classify into four groups: big data, social media, mathematical models and stochastic theory and machine learning techniques, the authors assure the urgency of incorporating into the forecast models considerations such as the multiple peaks that have been documented in the short term as well as tracking newly infected cases. Ekinci (2021) reaches similar conclusions since, based on the limitations indicated to the ARIMA models, it raises the need to consider the conditional variance and asymmetric effects, the heavy-tail distributions of the daily growth rate, which characterize the evolution of COVID - 19 pandemic. The author explores several possibilities of the generalized autoregressive conditional heteroscedasticity family of models -GARCH-, finding that the asymmetric ARMA-GARCH and GARCH specifications produce the best fits, according to the Mean Square Error (RMSE) criterion.

The ideas developed in the previous paragraphs bring a couple of essential aspects to the table for academic discussion. First, it is necessary to develop and implement early warning systems, allowing anticipating the unwanted effects caused by the SARS-Cov-2 virus in a more timely manner. Second, such efforts must recognize how the COVID-19 pandemic has been evolving. In this way, such early warning systems and prediction models must consider the conditional variance, the asymmetric effects, and the heavy-tailed distributions observed in the growth rate evolution of the new daily confirmed cases. This study aims to contribute to this effort. 


\section{Methodological Issues}

\subsection{COVID-19 Death Rates Tracking}

This section presents the COVID-19 tracking from total deaths using daily data from April 1, 2020, to September 20, 2021. This sample selection allows to gather homogeneous information for all countries studied and collected from Our World in Data open-source database. We use logarithmic differences to display the deaths rate as follows:

$$
R=\log \left(\frac{D_{t}}{D_{t-1}}\right)
$$

Where $R$ refers to death's rate, $D_{t}$ is the total deaths in time $\mathrm{t}$ and $D_{t-1}$ in the previous period. Figure 1 presents the evolution of the death rate. From April to June 2020, high death rates are concentrated in most countries due to the spread of COVID-19. As sanitary measures and lockdown to quash COVID-19 outbreaks were implemented, death rates decreased between 5\% to 2\%. Among the cases, India and Argentina stand out, showing rises in their death rate (close to 20\%) in June and October 2020, respectively, while Spain had a significant reduction (-5\%) in May 2020. Likewise, Colombia and Mexico had crucial rebounds on the same date, close to $10 \%$ growth rates.

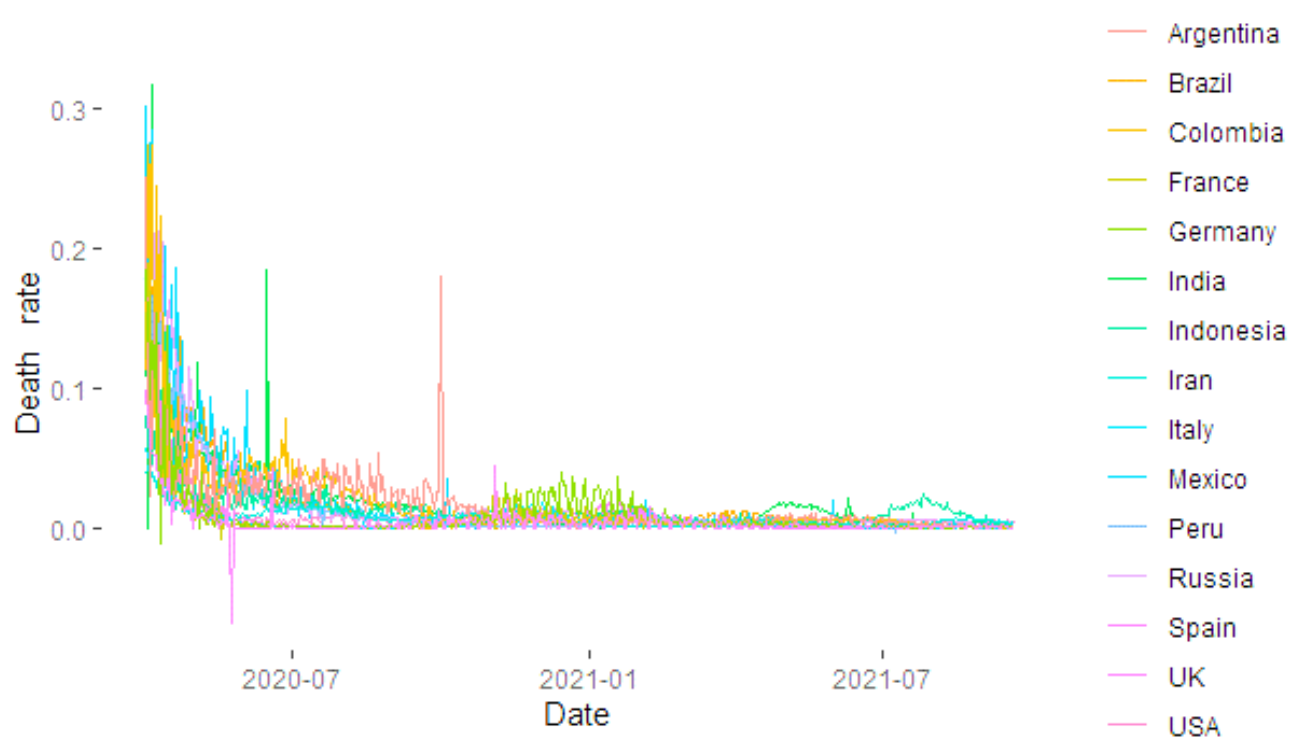

Figure 1. Death rate from April 2020 to September 2021

Nevertheless, the story in 2021 is different for the evolution of death's rates due to the approval of vaccines such as Pfizer / Biontech (Germany), AstraZeneca (United Kingdom), Moderna (USA), Johnson \& Johnson (USA), Sinovac (China), Cansino Biologics (China) to name some of the most popular and firstly approved. Likewise, the case of the Sputnik vaccine from Russia, despite not being supported by the WHO, is still one of the most efficient (Jones \& Roy, 2021).

Figure 2 represents only the death rates from January 2021 to September 20, 2021, where it is observed that the rates are reduced by at least $3 \%$ for the first quarter of 2021 in most countries except for Germany and the United Kingdom (UK). In addition, figure 2 also shows the effects of the Delta variant of COVID-19, which is characterized by a rebound in contagions and higher countries' death rates. Those that suffered the most significant damage in terms of deaths were India in April 2021 (close to 2\%), Mexico in June (close to 2\%), Indonesia in July exceeding 2\%, while the other countries were around $1 \%$. 


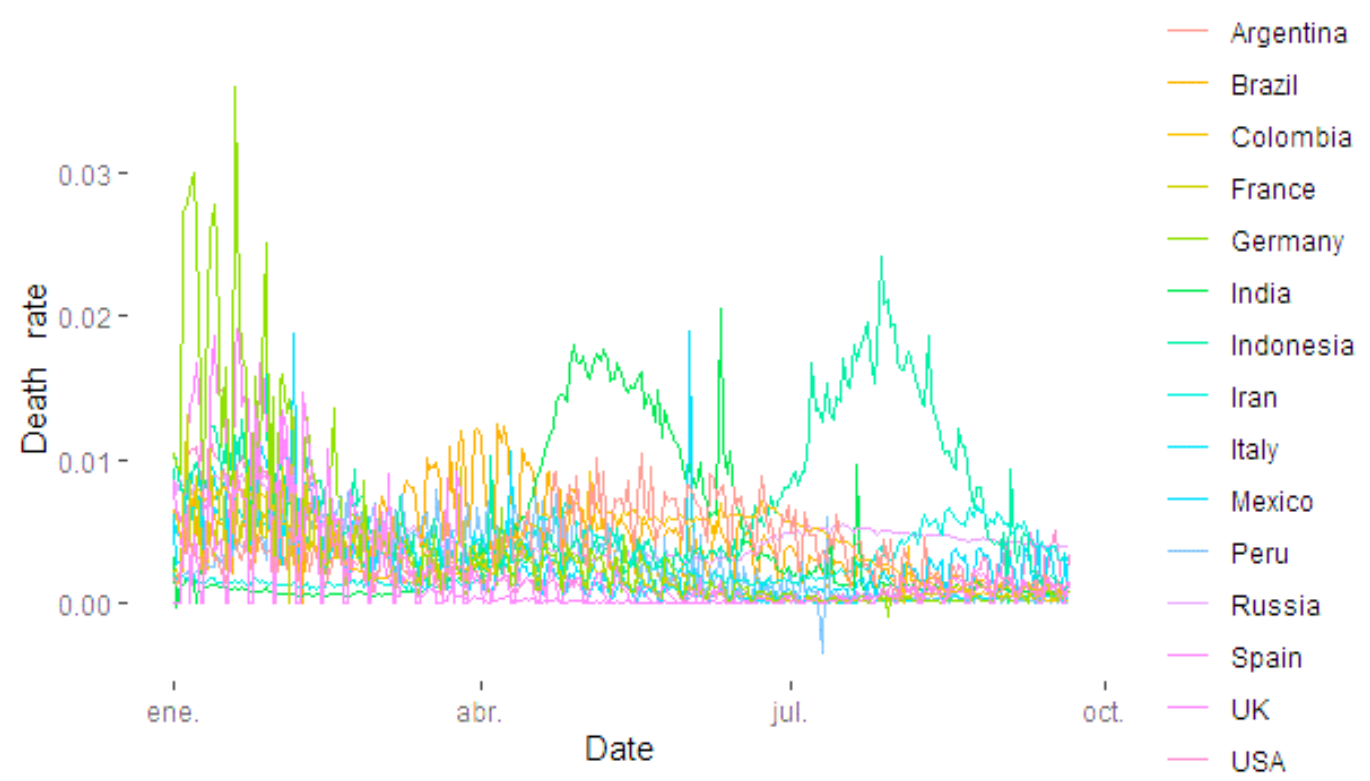

Figure 2. Death rate from January 2020 to September 2021

The differences between the annualized dispersions (standard deviation) also reflect a significant change. Table 2 shows that from April 2020 to September 2021, Mexico is the country that presents a more substantial variation in terms of death rates $(57.27 \%$ ), while Iran presents the minimum with $9.69 \%$. However, the data split by year shows that the highest growth rates involve Mexico with the highest volatility $(74.38 \%)$ and Iran with $10.18 \%$. Finally, from January 2020 to September 2021, Germany had the highest standard deviation (9.99\%) while Russia was the lowest with $2.40 \%$. Overall, there is a significant reduction in the standard deviation concerning the death rate in 2021 .

Table 2. Death rate from January 2020 to September 2021

\begin{tabular}{lccclccc}
\hline \multirow{2}{*}{ Country } & Annual & 2020 & 2021 & Country & Annual & 2020 & 2021 \\
& SD \% & SD \% & SD \% & & SD \% & SD \% & SD \% \\
\hline USA & 32.75 & 43.70 & 4.21 & Italy & 10.96 & 14.30 & 3.23 \\
Brazil & 46.42 & 60.87 & 4.49 & Colombia & 47.15 & 60.04 & 3.74 \\
India & 48.07 & 61.07 & 8.24 & Iran & 9.69 & 10.18 & 2.75 \\
Mexico & 57.27 & 74.38 & 4.80 & France & 26.59 & 36.19 & 3.74 \\
Peru & 45.49 & 59.47 & 3.83 & Argentina & 36.02 & 43.29 & 3.68 \\
Russia & 50.38 & 65.49 & 2.40 & Germany & 31.54 & 41.84 & 9.99 \\
Indonesia & 23.89 & 30.23 & 7.64 & Spain & 15.96 & 21.37 & 4.78 \\
UK & 32.01 & 43.17 & 6.72 & & & & \\
\hline
\end{tabular}

Note: SD for standard deviation

\subsection{ARIMA Approximation}

Since death rates represent each country's univariate (scalar) time series, we use an Auto-Regressive Integrated Moving Average (ARIMA) model to identify dependence from lagged observations and residual errors. Using the traditional Box \& Jenkins (1970) notation. The death rate throughout the time $\left(R_{t}\right)$ is now introduced with the ARIMA model, as shown in equation 2: 


$$
R_{t}=\mu+\sum_{i=1}^{p} \psi_{i} R_{t-i}+\sum_{i=1}^{p} \theta_{i} u_{t-i}+u_{t} \quad, u_{t} \sim N\left(0, \sigma^{2}\right)
$$

Where $R_{t}$ is the current value of the series and depends linearly on its previous values (Autoregressive -AR- Process) and last noises (Moving Average -MA-process) plus the error term that is assumed to be white noise, meaning that the process is stationary. We use the Augmented Dickey-Fuller (ADF) test for unit root detection, if $R_{t}$ rejects the null hypothesis of unit root presence, then it is assumed that $R_{t}$ is stationary in a weak sense; meaning that death rates have a constant mean and variance for all the samples $\left(u_{t} \sim N\left(0, \sigma^{2}\right)\right)$. Table 3 display the results for the ADF test.

Table 3. Augmented Dickey-Fuller test for death rates

\begin{tabular}{lclc}
\hline \multicolumn{1}{c}{ Country } & ADF Test & Country & ADF Test \\
\hline \multirow{2}{*}{ USA } & -0.1433 & Italy & -0.2564 \\
& $(0.9999)$ & & $(0.9999)$ \\
\hline \multirow{2}{*}{ Brazil } & -1.7532 & \multirow{2}{*}{ Colombia } & -0.9923 \\
& $(0.6798)$ & & $(0.9383)$ \\
\hline \multirow{2}{*}{ India } & -1.1403 & \multirow{2}{*}{ Iran } & -1.2084 \\
& $(0.9146)$ & & $(0.9036)$ \\
\hline \multirow{2}{*}{ Mexico } & -1.9274 & \multirow{2}{*}{ France } & -1.232 \\
& $(0.6065)$ & & $(0.8994)$ \\
\hline \multirow{2}{*}{ Peru } & $-3.9407 * *$ & \multirow{2}{*}{ Argentina } & -0.8237 \\
& $(0.0124)$ & & $(0.9586)$ \\
\hline \multirow{2}{*}{ Russia } & -2.015 & \multirow{2}{*}{ Germany } & -3.0723 \\
& $(0.5696)$ & & $(0.1243)$ \\
\hline \multirow{2}{*}{ Indonesia } & -0.8735 & \multirow{2}{*}{ Spain } & $(0.7018)$ \\
\hline \multirow{2}{*}{ UK } & $(0.9542)$ & & \\
& -0.6842 & & \\
\hline
\end{tabular}

Note. The Dickey-Fuller statistic is reported, and the p-value is in parentheses to test the null hypothesis that death rates have a unit root. The symbols $*, * *$ and $* * *$ denote significance at $10 \%, 5 \%$ and $1 \%$ respectively.

Table 3 indicates that all mortality rates, except for Peru, present unit root problems. In that sense, it is necessary to capture the autocorrelated values in the AR and MA components to eliminate unit root problems. Table 4 exhibits the results of combining different numbers of lags $(p, q)$ for AR and MA. The Akaike criterion (AIC) is used to define the model that best fits the series performance.

Table 4. Best ARIMA fitting

\begin{tabular}{lcclrc}
\hline \multicolumn{1}{c}{ Country } & $\begin{array}{c}\text { Best ARIMA } \\
\text { fitting }\end{array}$ & AIC & Country & $\begin{array}{c}\text { Best ARIMA } \\
\text { fitting }\end{array}$ & AIC \\
\hline USA & $(2,0,4)$ & -2815.3366 & Italy & $(4,0,0)$ & -3094.9894 \\
Brazil & $(1,0,0)$ & -2547.2585 & Colombia & $(2,0,0)$ & -3164.4818 \\
India & $(3,0,0)$ & -2714.3175 & Iran & $(1,0,2)$ & -3326.3698 \\
Mexico & $(2,0,0)$ & -2403.9471 & France & $(5,0,0)$ & -2660.6084
\end{tabular}




\begin{tabular}{llllll} 
Peru & $(4,0,0)$ & -2802.6155 & Argentina & $(4,0,0)$ & -2619.6799 \\
Russia & $(3,0,1)$ & -3316.4354 & Germany & $(1,0,3)$ & -2208.3170 \\
Indonesia & $(1,0,2)$ & -2596.6046 & Spain & $(5,0,2)$ & -2468.4010 \\
UK & $(2,0,1)$ & -2631.2499 & & & \\
\hline
\end{tabular}

Once the ARIMAs estimators are obtained, the Ljung Box test is performed on the residuals to verify if autocorrelation problems are solved. A significant p-value rejects the null hypothesis that the time series does not present autocorrelation. Another way to interpret this test is that residuals are independently distributed. Likewise, the ARCH effects test is incorporated to identify non-linear autocorrelation in the squared residuals. The ARCH effects test for the null hypothesis of homoscedastic residuals from the ARIMA output. Table 5 shows the results.

Table 5. Residual test

\begin{tabular}{lcllcl}
\hline \multicolumn{1}{c}{ Country } & $\begin{array}{c}\text { Ljung-Box } \\
(\mathrm{p} \text {-value })\end{array}$ & $\begin{array}{c}\text { ARCH-Effects } \\
(\mathrm{p} \text {-value })\end{array}$ & Country & $\begin{array}{c}\text { Ljung-Box } \\
(\mathrm{p}-\text {-value })\end{array}$ & $\begin{array}{c}\text { ARCH-Effects } \\
(\mathrm{p}-\text {-value })\end{array}$ \\
\hline USA & 0.8585 & $0.000^{* * *}$ & Italy & 0.5056 & $0.000^{* * *}$ \\
Brazil & 0.7167 & $0.000^{* * *}$ & Colombia & 0.2464 & $0.000^{* * *}$ \\
India & 0.9906 & 0.9999 & Iran & 0.9903 & $0.000^{* * *}$ \\
Mexico & 0.4372 & 0.2094 & France & 0.8908 & $0.000^{* * *}$ \\
Peru & 0.3130 & $0.0057 * *$ & Argentina & 0.7432 & 0.1819 \\
Russia & 0.3105 & $0.000^{* * *}$ & Germany & 0.9144 & $0.000^{* * *}$ \\
Indonesia & 0.9660 & 0.4134 & Spain & 0.9770 & $0.000^{* * *}$ \\
UK & 0.0697 & $0.000^{* * *}$ & & & \\
\hline
\end{tabular}

Table 5 shows that the autocorrelation problems are solved from the ARIMAs estimation for each country. For the ARCH effects test, the homoscedasticity of the residuals is rejected for all countries except for India, Mexico, Indonesia, and Argentina. Hence, it is necessary to incorporate additional information into the ARIMA proposals to measure the clustering formation of death rates (causing the non-linear autocorrelation of the residuals). In this sense, we use an Exponential Generalized Autoregressive Conditional Heteroscedasticity (EGARCH). EGARCH models allow capturing volatility clustering and the asymmetry effects in death rates for all countries.

\section{Results Discussion}

\subsection{Conditional Variance}

To capture volatility clusters in $R_{t}$, we start from a Generalized Autoregressive Conditional Heteroscedasticity (GARCH) model defining $\sigma^{2}$ from equation 1 as the conditional variance of $u_{t}$ (equation 3).

$$
\sigma_{t}^{2}=u_{t}^{2}\left(u_{t} \mid u_{t-1}, u_{t-2}, \ldots, u_{t-q}\right)
$$

Being $\sigma_{t}^{2}$ the squared residual conditioned to its lagged squared errors (ARCH process). By making $\sigma_{t}^{2}$ recursive and allowing the conditional variance to be dependent on its lags, the equation for the conditional variance is:

$$
\sigma_{t}^{2}=\omega+\alpha_{1} u_{t-1}^{2}+\beta_{1} \sigma_{t-1}^{2}
$$

Equation 4 represents a $\operatorname{GARCH}(1,1)$ process where $\sigma_{t}^{2}$ is the conditional variance, $\omega$ is the intercept of variance equation, $\alpha_{1} u_{t-1}^{2}$ is the ARCH process indicating the previous volatility, and $\beta_{1} \sigma_{t-1}^{2}$ is the fitted variance in the last period. Nevertheless, the GARCH models are symmetric, meaning no difference between positive and negative shocks on conditional volatility. Likewise, GARCH models lack leverage effects, omitting shocks magnitude over $\sigma_{t}^{2}$, whether positive or negative (McAleer, 2015). We consider the traditional Nelson (1991) EGARCH $(1,1)$ model to capture asymmetry effects in equation 5 . 


$$
\ln \left(\sigma_{t}^{2}\right)=\omega+\alpha\left(z_{t-1}\right)+\gamma\left(z_{t-1}\right)+\beta\left(\ln \left(\sigma_{t-1}^{2}\right)\right)
$$

Nelson's (1991) proposal allows no sign restrictions on $(\omega, \alpha, \gamma)$. The $\gamma$ indicates whether the asymmetry exists for EGARCH when $\gamma>0$. Leverage effects show up when $\gamma<0$ and $\gamma<\alpha<-\gamma$. (Ramírez \& Jiménez, 2021) The results of all estimations, including the ARIMA mean equations, are represented in appendix 1. For all the countries, $\gamma>0$ confirms the asymmetry effects. It is worth noting that a skewed t-Student distribution is used to catch fat tail formations in death rates.

$$
f\left(z_{t} \mid \xi, v\right) \begin{cases}\frac{2 \sigma}{\xi+\xi^{-1}} g\left[\xi\left(s z_{t}+\mu \mid v\right)\right], & , z_{t}<-\frac{\mu}{\sigma} \\ \frac{2 \sigma}{\xi+\xi^{-1}} g\left[\xi\left(s z_{t}+\mu \mid v\right)\right], & , z_{t} \geq-\frac{\mu}{\sigma}\end{cases}
$$

Where $z_{t}$ is distributed as a skewed t-Student and $g\left[\left(z_{t}+\mu \mid v\right)\right]$ is the density function. Parameter $\xi$ refers to symmetry, and $v$ determines the presence of fat tails. Finally, both $\mu$ and $\sigma$ are the traditional mean and variance parameter for a noncentral t-distribution.

$$
\begin{gathered}
\mu=\frac{\Gamma\left(\frac{v-1}{2}\right) \sqrt{v-2}}{\sqrt{\pi} \Gamma\left(\frac{v}{2}\right)} \\
\sigma=\left(\xi^{2}+\frac{1}{\xi^{2}}-1\right)-\mu^{2}
\end{gathered}
$$

\subsection{ARMA-EGARCH Rolling Window and Forecast Fitting}

Figures 3 to 10 show the annualized volatility of death rates (black line) while the estimated volatility ( $\left.\hat{\sigma}_{t}^{2}\right)$ is represented by the red line and is also annualized. Both annualized volatility and estimated volatility are seven days smoothed to show the weekly performance of death rates $(R)$. Likewise, we compute the rolling conditional volatility from ARMA-EGARCH models with seven days refitting to get estimations accuracy.
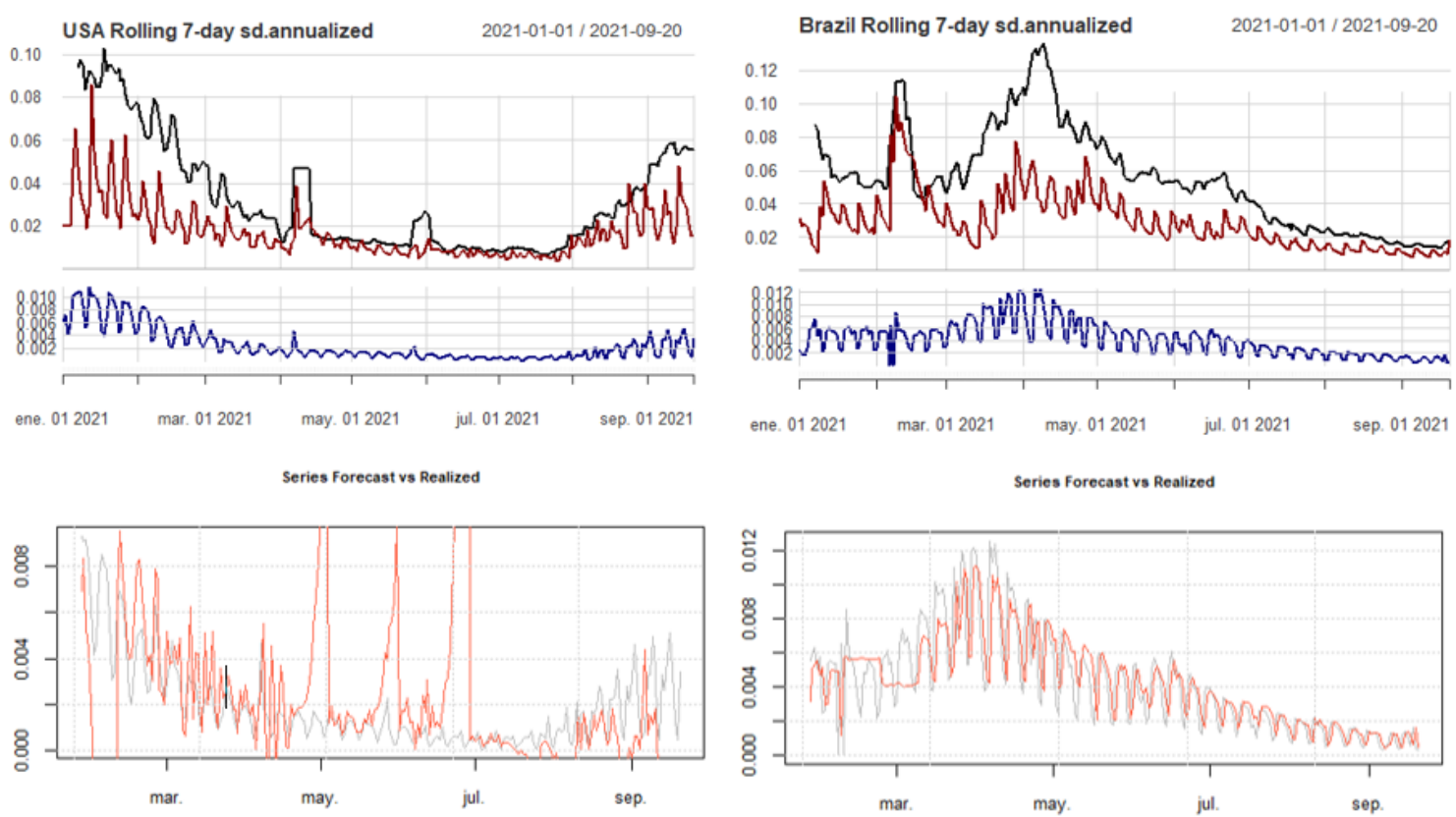

Figure 3. Seven days rolling conditional volatility vs. tracking: USA and Brazil 
Figure 3 presents the annualized volatility in a 7-day rolling window vs. the track estimated from the ARMA-EGARCH models proposed for each country. Below them are the absolute returns in terms of COVID-19 deaths. In the United States panel, the annualized death rates decrease from $10 \%$ to $2 \%$ from January to July 2021 ; however, the track shows the rebound in deaths from August 2021 to reach a maximum of $6 \%$ at the end of September 2021. Regarding the predicted vs. realized conditional volatility, the result shows overestimations in some points of May, June, and July, resulting from the sudden rises of 4 and 3\% in May and June, respectively. In this sense, the better adjustment corresponds to Brazil; the forecast better captures its volatility. The latter is also reflected on the track, slightly ahead of Brazil's 12\% increase in deaths in April 2021.
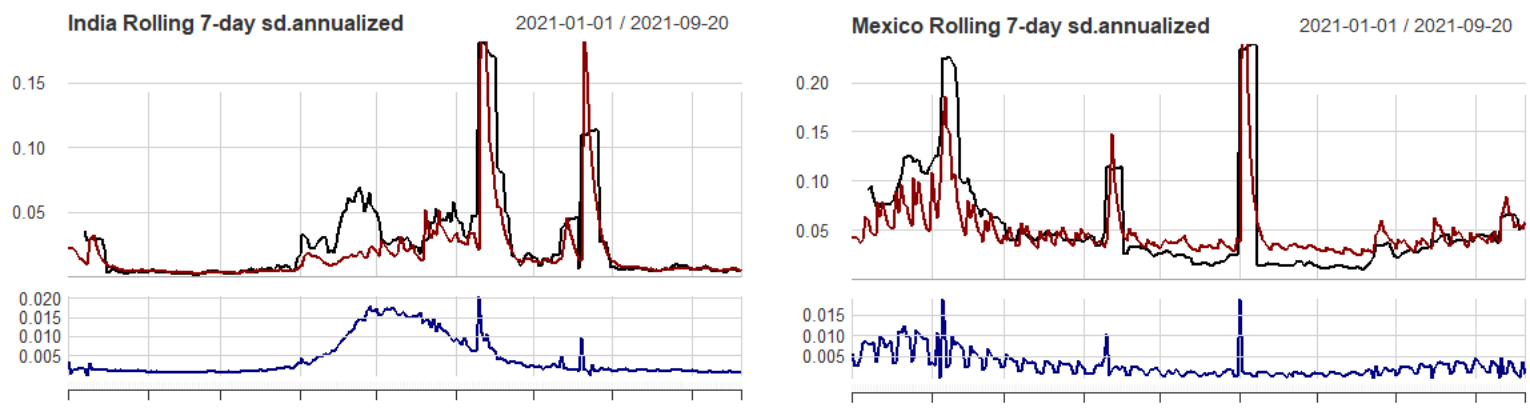

ene. 012021 mar. $012021 \quad$ may. $012021 \quad$ jul. $012021 \quad$ sep. 012021
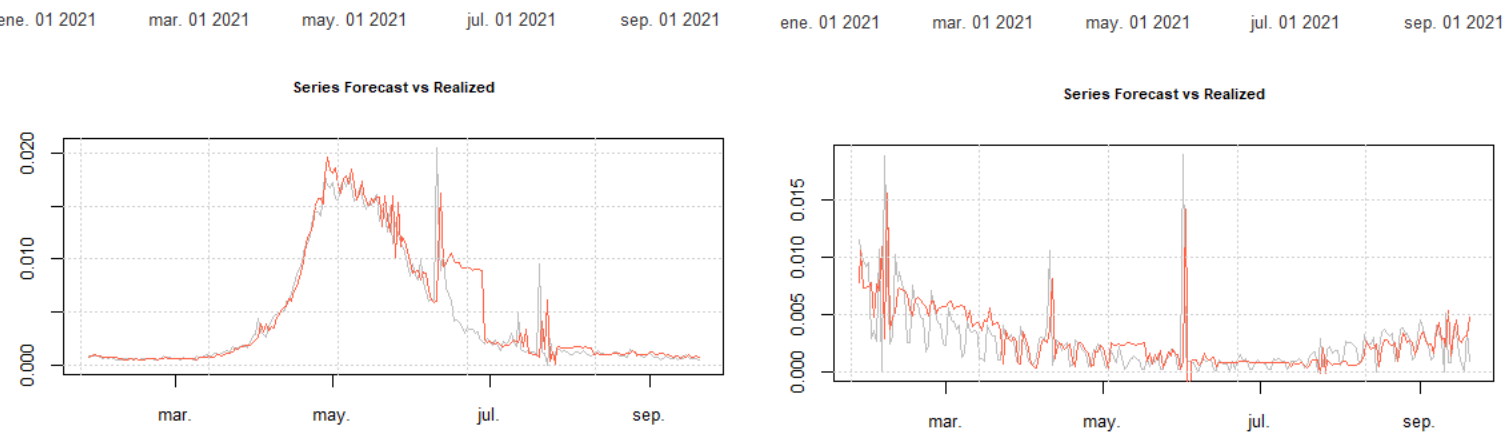

Figure 4. Seven days rolling conditional volatility vs. tracking: USA and Brazil

Figure 4 shows a similar analysis for India and Mexico. India's track adapts appropriately to the volatility peaks of death rates. Its highest dispersion was $15 \%$ in July and approximately $10 \%$ in August. After the sharp rebound in July, the forecast overfitted the volatility's impact and stabilized about 15 days later to re-adjust its behavior. In Mexico's case, figure 4 shows an increase in death rates in February, May, and July 2021 of 20\%, 15\%, and 22\%, respectively. In both cases, the track correctly follows the conditional volatility direction in a weekly window. At the same time, a robust adjustment is also observed for the forecast, considering the moments of most outstanding dispersion. Hence, the ARMA-EGARCH track for Mexico turns out to be one of the most accurate. 

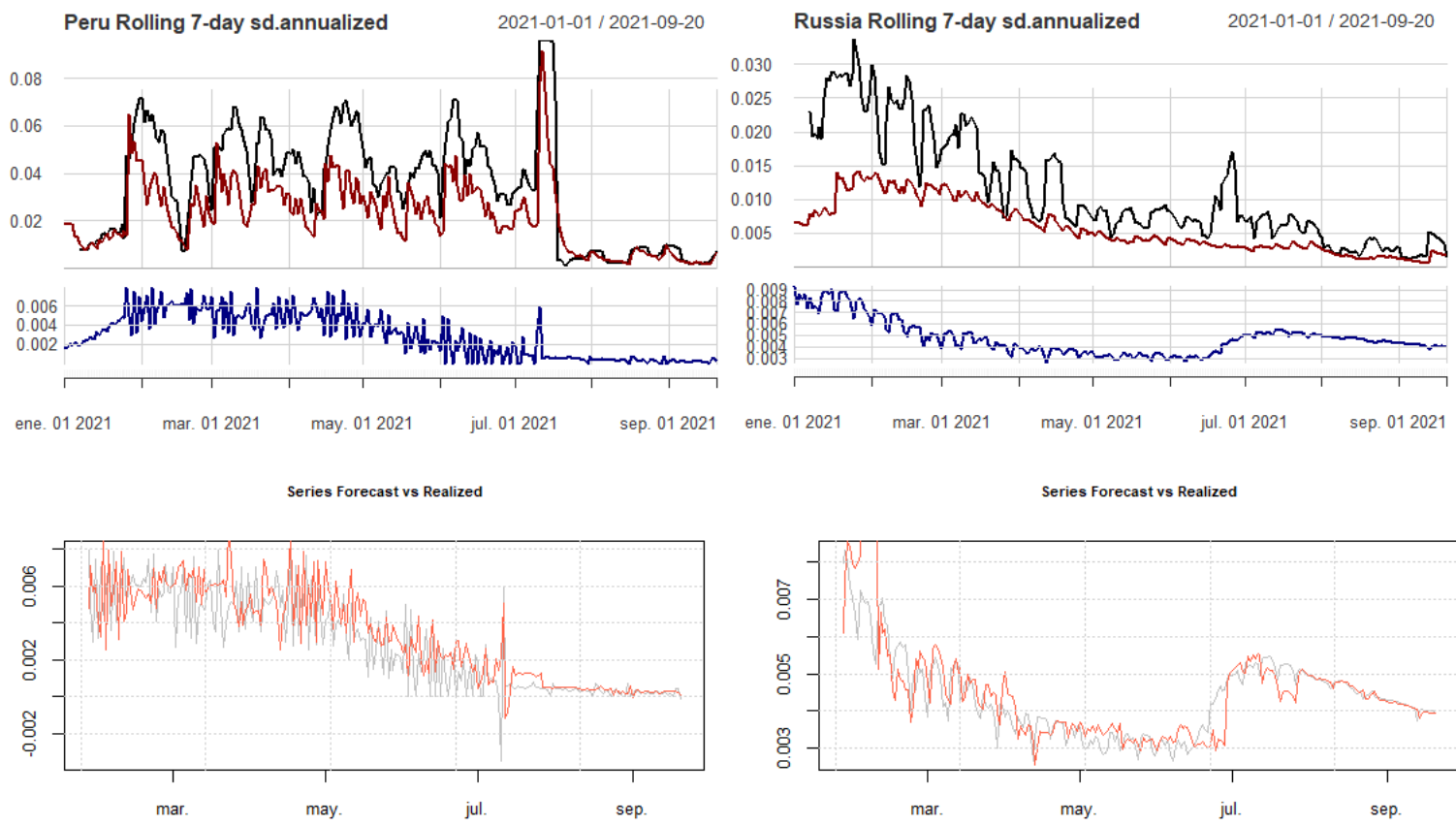

ene. $012021 \quad$ mar. $012021 \quad$ may. $012021 \quad$ jul. $012021 \quad$ sep. 012021

Figure 5. Seven days rolling conditional volatility vs. tracking: Peru and Russia

Figure 5 shows the annualized rolling window for Peru and Russia. Peru has more death rates volatility fluctuating between 2\% and 6\% from February to June 2021. Its highest rebound was in July 2021 with 8\%, and after that, the volatility of death rates remained below $2 \%$. Peru's volatility forecast has a good fit except for March, when the prediction overestimates actual data. The track for Russia shows in a general way the gradual fall that the country has had in death rates. During some moments of volatility, such as June 2021, the track does not fully catch this peak in the rolling window. For the daily forecast, the estimate reacts to the increase in death rates in July, remaining accurate to the volatility registered until September 2021.
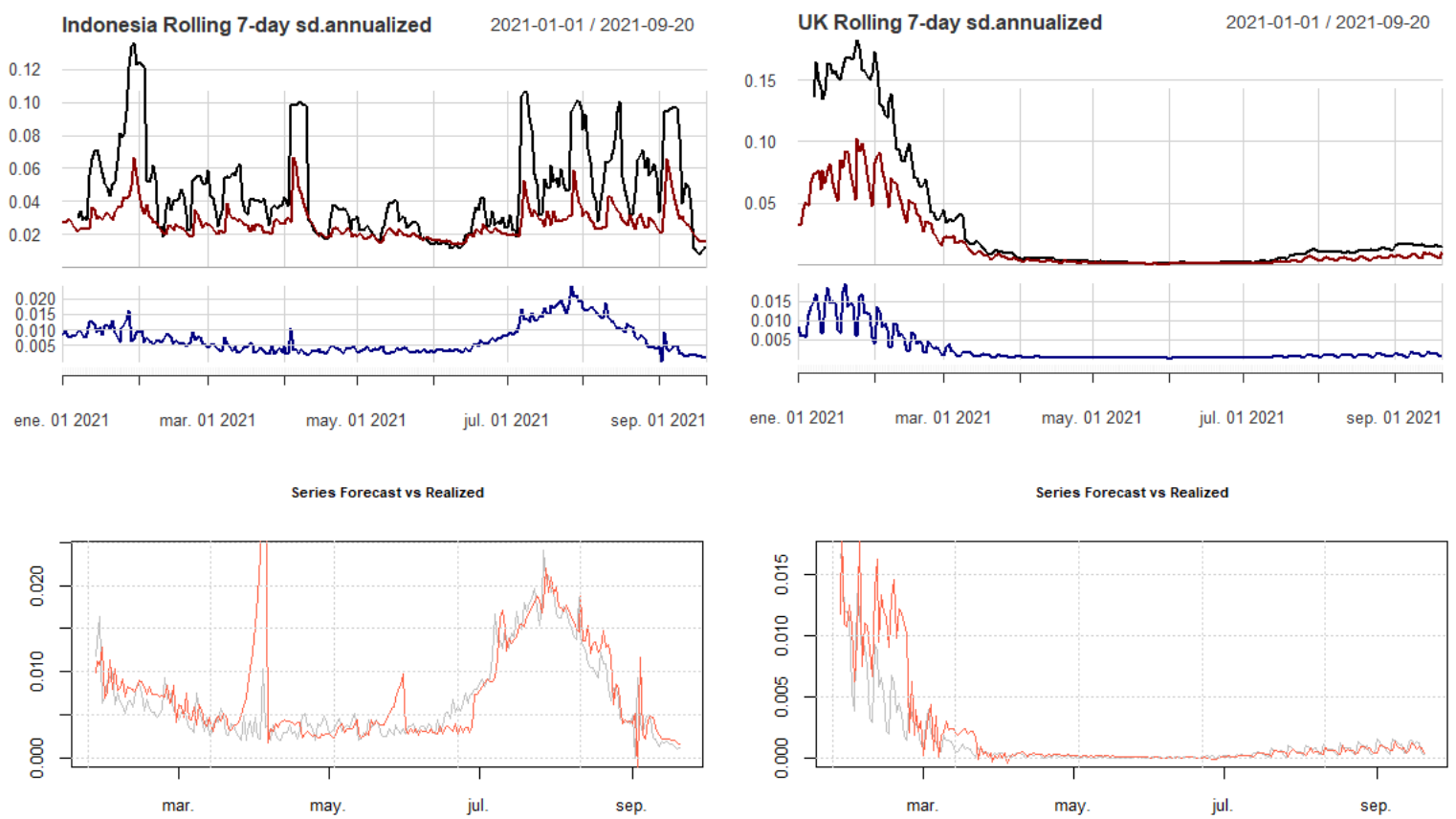

Figure 6. Seven days rolling conditional volatility vs. tracking: Indonesia and UK 
Figure 6 offers corresponding Indonesia and the UK analysis. The first country has the highest levels of volatility in February (13\%), April (10\%), and from July to September with peaks of $10 \%$ as well. The resulting track captures these movements, and in terms of forecasts, the only lag is in February, where the model overestimates the volatility of death rates. The sharp fall in UK's death rates volatility stands out, going from 15\% in January 2021 to less than $1 \%$ from April to September 2021, with rises close to $1 \%$ in September. The forecast overfits February's values for the UK. For the rest of the series, the model fits appropriately.
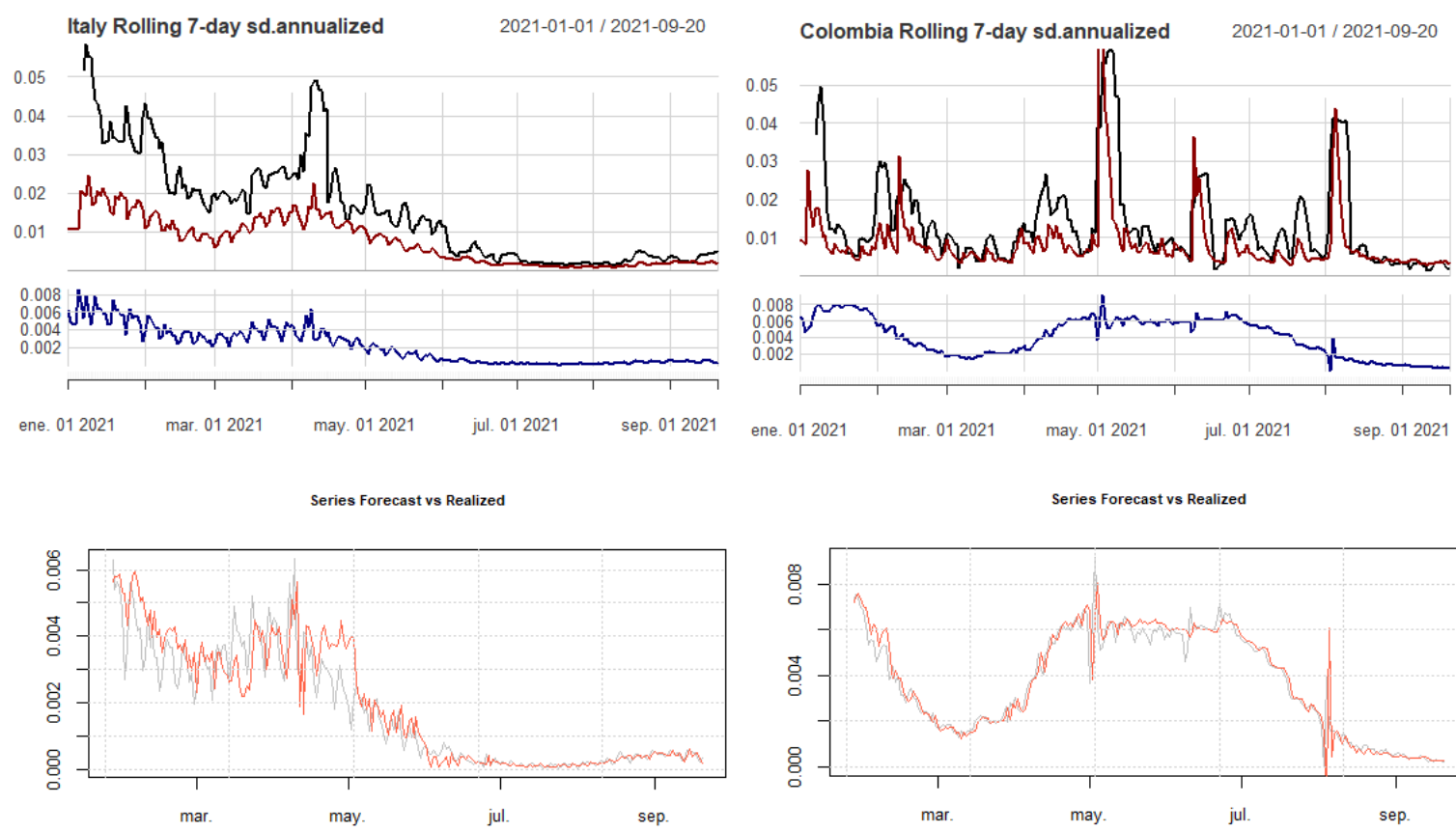

Figure 7. Seven days rolling conditional volatility vs. tracking: Italia and Colombia

Figure 7 shows the results for Italy and Colombia. The highest Italy's death rates correspond to January (5\%) and April (4.9\%); the track correctly follows the deaths rate's volatility. The forecast offers a good fit except for May. Colombia's rolling weekly window has one of the best adjustments of all countries in the sample; it generates an accurate track for all the volatility peaks generated in May, July, and September with rates of 5\%, 4\%, and 4.5\%, respectively. The forecast also fits well when capturing the greatest dispersion moments. 

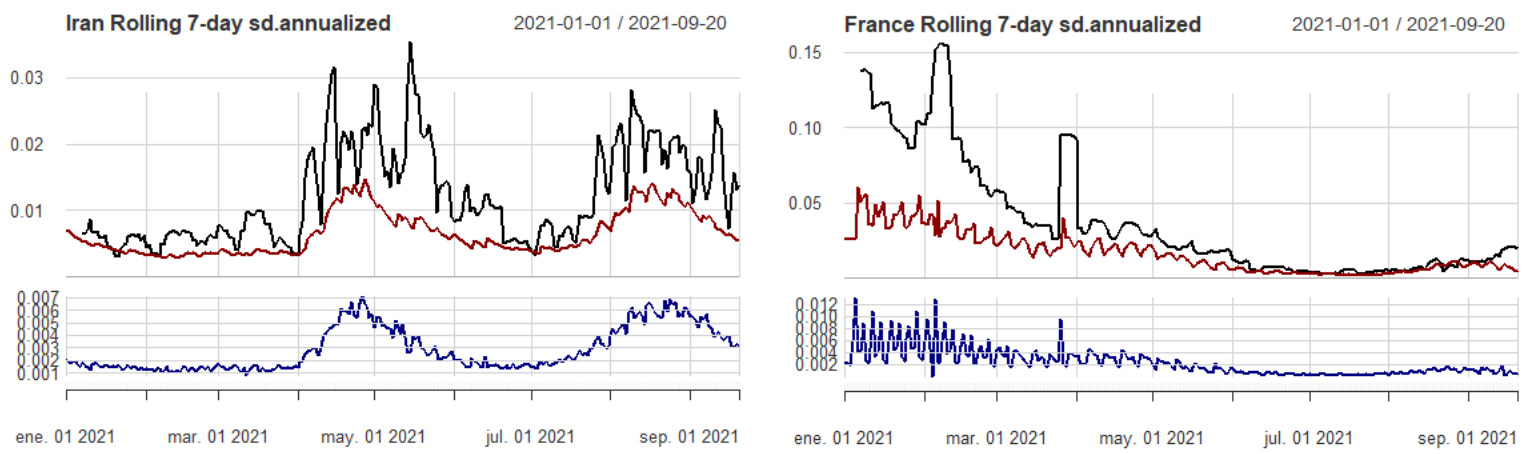

Series Forecast vs Realized
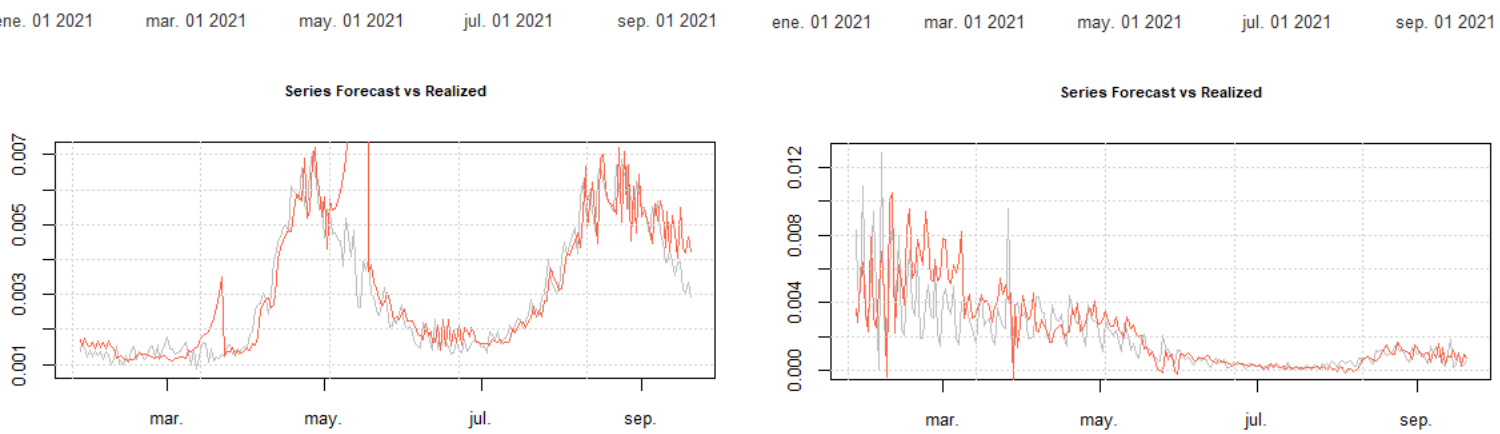

Figure 8. Seven days rolling conditional volatility vs. tracking: Iran and France

Figure 8 includes the results of Iran and France. Iran's death rate volatility in May (3 peaks of 3\% each), August, and September $2021(2 \%)$. Despite this, Iran's death rate volatility is lower than some countries analyzed (such as Indonesia, Mexico, or India), where the peaks in death rates reach up to $10 \%$. Italy's death rate volatility forecasted is consistent except for May, where the forecast overestimates real value. Although France's track generally follows the death rates behavior, April's effect shows a 10\% rebound. The previous is consistent with the forecast; there is a lag between the estimation and the observed volatility for the first months.
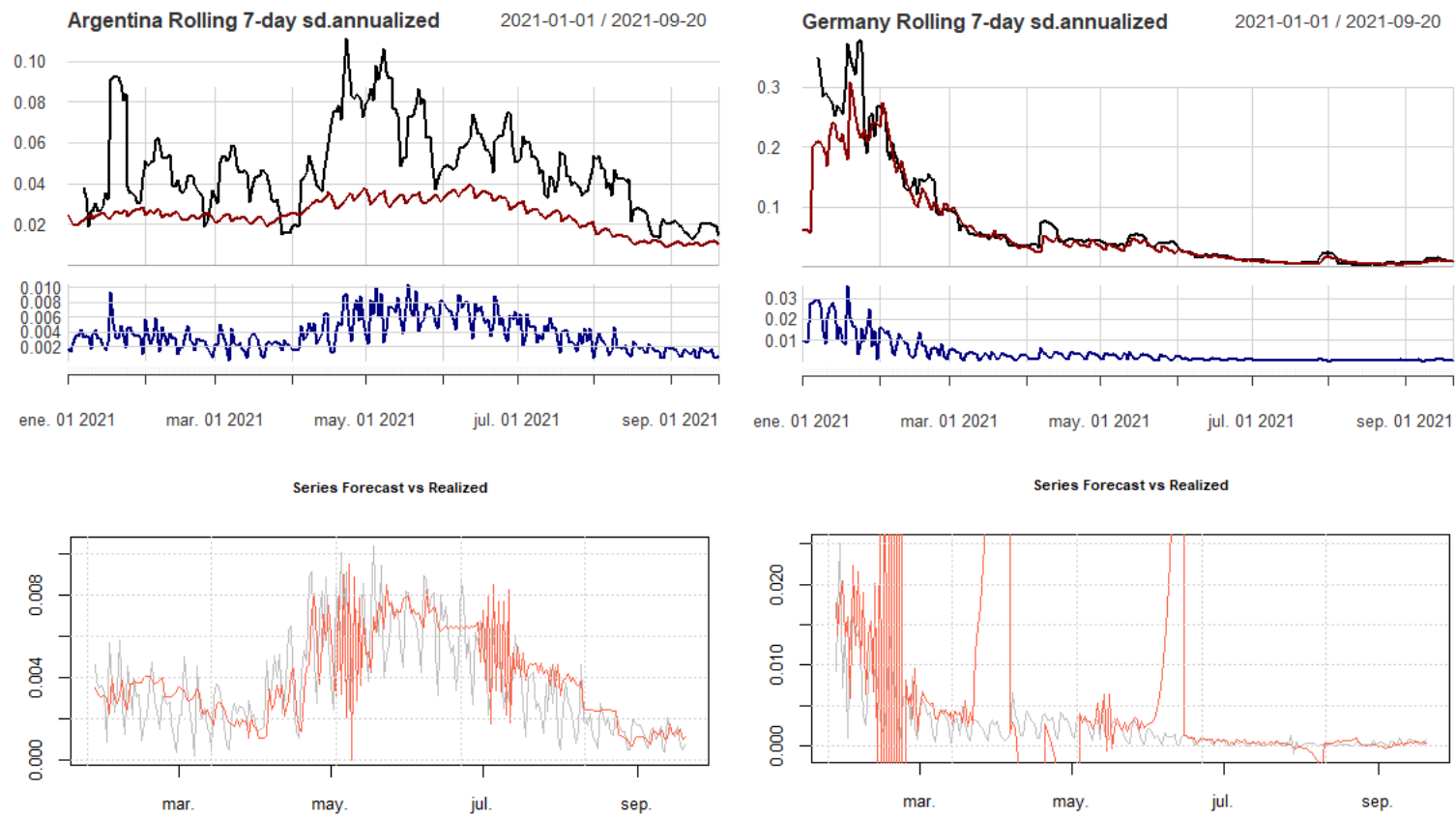

Figure 9. Seven days rolling conditional volatility vs. tracking: Argentina and Germany 
Figure 9 displays the corresponding analysis for Argentina and Germany. Argentina's track underestimates the effects of death rates volatility, with values oscillating between 4 and $8 \%$ for most of the sample, except May with peaks of $10 \%$ and a substantial decrease of 3\% in September 2021. On the other hand, Germany's track correctly records the behavior at the end of January 2021; however, this country presents a similar situation to the UK, where it goes from a high death rate (30\%) to below $1 \%$ as of June 2021. February's forecast offers a significant inconsistency as in April and June 2021, with a couple of overestimated values in daily volatility.
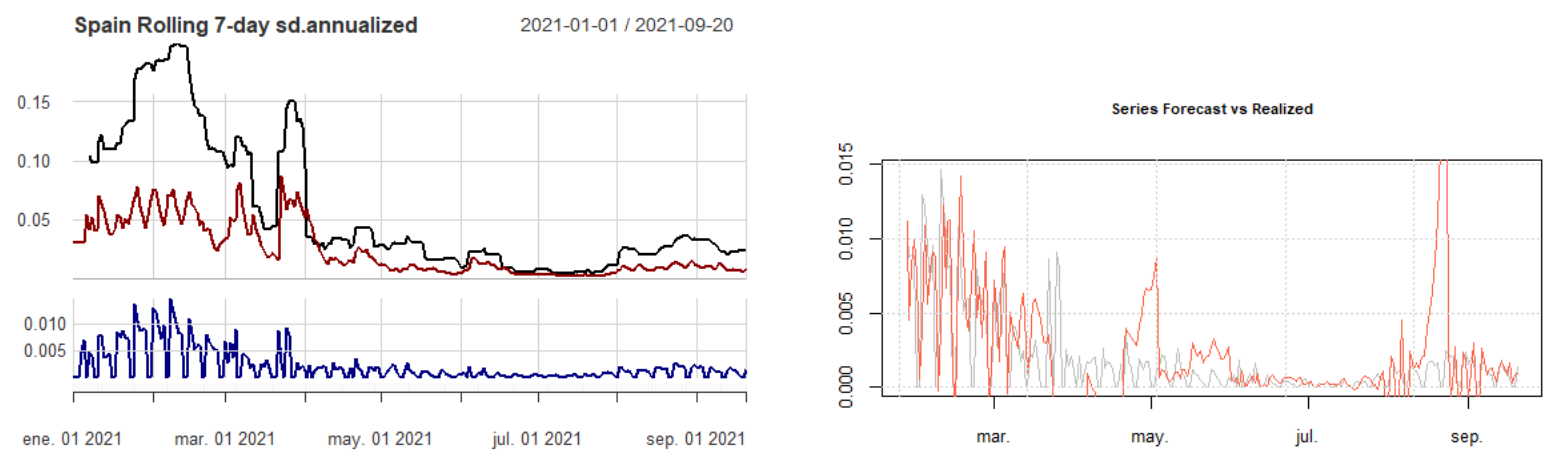

Figure 10. Seven days rolling conditional volatility vs. tracking: Spain

Finally, Figure 10 shows Spain's results. The track appropriately follows the annualized volatility in the rolling weekly window. However, an underfitting forecast is observed in April 2021, and two overestimates in May and early September for daily conditional volatility.

\section{Conclusions}

The resulting SARS-COV-2 coronavirus pandemic revealed significant levels of weakness and vulnerability in the health, social, economic, and political institutions to face the unexpected health crisis. The former is consistent with the havoc in several aspects of the human dynamic, considering multiple health and economic ravages caused by the COVID-19 pandemic. To better understand the spread's pandemic dynamic, containment techniques, and the design of strategies to face its multiple harmful effects, the entire scientific community has committed to analysing the causes and consequences of the new coronavirus from a holistic perspective. Efforts that allow forecasting the evolution of SARS-COV-2 through new infections and deaths is an urgent and essential activity.

This work contributes to these concerns by offering empirical evidence on the pandemic's daily deaths behavior in the most affected countries after the approval, distribution, and implementation of vaccines, from April 1, 2020, to September 20, 2021. Starting with an Autoregressive Integrated Moving Average (ARIMA) specification, we estimate the total death conditional variance, using an exponential Generalized Autoregressive Conditional Heteroscedasticity model (EGARCH). Finally, we calculated a rolling backtesting within a 7-day rolling window to demonstrate the robustness of our COVID-19 mortality forecast.

Overall, our estimates accurately track death rates volatility in all the countries analysed; the best adjustments correspond to Colombia, Indonesia, Mexico, and Peru. Notwithstanding, in some cases (USA, Iran, Argentina, Germany, and Spain), the forecast overestimates the daily death rates volatility, being the main limitation of the study. However, it is essential to remark the forecast quickly adjusts to the actual behavior of the series.

Future research should improve understanding of the spread of the new contagion cases dynamics. For example, other time series approaches allow the analysis of impulse-response functions, considering the effect of extreme values in the prediction models and exploring potential effects of cointegration with different economic and health phenomena. Likewise, it is worth considering other models of the GARCH family that also assume asymmetric effects, such as the Threshold GARCH (T-GARCH) or GJR-GARCH models, to name just a few.

Beyond proposing a methodology to track the spread rate of the COVID-19 pandemic from the information contained in the volatility clusters of new infections, the study's main contribution is that the results obtained can contribute to the design of strategies allowing anticipate unexpected shocks. 


\section{References}

Ali, M., Alam, N., \& Rizvi, S. (2020). Coronavirus (COVID-19) - An epidemic or pandemic for financial markets. Journal of Behavioral and Experimental Finance, 27, 1-6. https://doi.org/10.1016/j.jbef.2020.100341

Box, G. E., \& Jenkins, G. M. (1970). Time Series Analysis Forecasting. San Francisco: Holden-Day.

Cakmakli, C., Demiralp, S., Kalemli-Ozcan, S., Yesiltas, S., \& Yildirim, M. (2020). COVID-19 and Emerging Markets: An Epidemiological Model with International Production Networks and Capital Flows. International Monetary Fund IMF Working paper series(20/133), 1-75. Retrieved from https://ssrn.com/abstract=3670613

Ceylan, Z. (2020). Estimation of COVID-19 prevalence in Italy, Spain, and France. Science of The Total Environment, 729(138817). https://doi.org/10.1016/j.scitotenv.2020.138817

Daehler, T., Aizenman, J., \& Jinjarak, Y. (2021). Emerging markets sovereign CDS spreads during COVID-19: Economics versus epidemiology news. Economic Modelling, 100(105504). https://doi.org/10.1016/j.econmod.2021.105504

De Salles, A. (2021). COVID-19 Pandemic Initial Effects on the Idiosyncratic Risk in Latin America. The Mexican Journal of Economics and Finance, 16(3), 1-21. https://doi.org/10.21919/remef.v16i3.632

Ekinci, A. (2021). Modelling and forecasting of growth rate of new COVID-19 cases in top nine affected countries: Considering conditional variance and asymmetric effect. Chaos, Solitons \& Fractals, 151(111227). https://doi.org/10.1016/j.chaos.2021.111227

Jones, I., \& Roy, P. (2021). Sputnik V COVID-19 vaccine candidate appears safe and effective. The Lancet, 397(10275), 642-643. https://doi.org/10.1016/S0140-6736(21)00191-4

Mackellar, L. (2007). Pandemic Influenza: A Review. Population and Development Review, 33, 429-451. https://doi.org/10.1111/j.1728-4457.2007.00179.x

McAleer, M. (2015). Asymmetry and Leverage in Conditional Volatility Models. Econometrics, 2, $145-150$. https://doi.org/10.3390/econometrics2030145

Nelson, D. (1991). Conditional heteroskedasticity in asset returns: A new approach. Econometrica, 59, 347-370. https://doi.org/10.2307/2938260

Ramírez, A., \& Jiménez, A. (2021). COVID-19 and Economics Forecasting on Advanced and Emerging Countries. EconoQuantum, 18(1), 21-43. https://doi.org/10.18381/eq.v18i1.7222

Rodríguez, B., Gurrola, C., \& López, F. (2021). Dependence of the stock markets of Argentina, Brazil and Mexico with respect to the U.S.: Covid19 and other recent financial crises. The Mexican Journal of Economics and Finance, 16(3), 1-18. https://doi.org/10.21919/remef.v16i3.652

Sahai, A., Rath, N., Sood, V., \& Singh, M. (2020). ARIMA modelling \& forecasting of COVID-19 in top five affected countries. Diabetes \& Metabolic Syndrome: Clinical Research \& Reviews, 14(5), 1419-1427. https://doi.org/10.1016/j.dsx.2020.07.042

Shinde, G., Kalamkar, A., Mahalle, P., Dey, N., Chaki, J., \& Hassanien, A. (2020). Forecasting Models for Coronavirus Disease (COVID-19): A Survey of the State-of-the-Art. Computer Science, 1(197). https://10.1007/s42979-020-00209-9

Wang, Y., Xu, C., Wang, Z., Zhang, S., Zhu, Y., \& Yuan, J. (2018). Time series modeling of pertussis incidence in China from 2004 to 2018 with a novel wavelet based SARIMANAR hybrid model. Plos One, 13(12), 1-23. https://doi.org/10.1371/journal.pone.0208404

\section{Notes}

Note 1 . The growth rate of emerging markets was already showing signs of retreat since 2013 with the taper tantrum, a term used to describe the markets' reaction to the reduction of expansionary policies carried out by the Federal Reserve -FED.

Note 2. See Ekinci (2021) for a comprehensive review of studies that have addressed forecasts of the COVID-19 pandemic by using ARIMA models. 


\section{Appendix 1. Estimation Output From ARMA(p,q) and EGARCH(1,1)}

\begin{tabular}{|c|c|c|c|c|c|c|c|c|c|c|c|c|c|c|c|c|}
\hline Country & Model & $\mu$ & $R_{t-1}$ & $R_{t-2}$ & $R_{t-3}$ & $R_{t-4}$ & $R_{t-5}$ & $u_{t-1}$ & $u_{t-2}$ & $u_{t-3}$ & $u_{t-4}$ & $\omega$ & $\alpha$ & $\beta$ & $\gamma$ & Shape \\
\hline USA & $\begin{array}{c}\text { ARMA } \\
(2,4)\end{array}$ & $\begin{array}{l}0.01 \\
* * *\end{array}$ & $\begin{array}{l}0.73 \\
* * *\end{array}$ & $\begin{array}{l}0.18 \\
* * *\end{array}$ & & & & $\begin{array}{l}0.75 \\
* * *\end{array}$ & $\begin{array}{l}0.67 \\
* * *\end{array}$ & $\begin{array}{l}0.64 \\
* * *\end{array}$ & $\begin{array}{c}0.3 \\
4 \\
* * *\end{array}$ & $\begin{array}{l}-1.47 \\
* * *\end{array}$ & $\begin{array}{l}0.66 \\
* * *\end{array}$ & $\begin{array}{l}0.89 \\
* * *\end{array}$ & $\begin{array}{c}0.04 \\
* *\end{array}$ & $\begin{array}{l}5.24 \\
* * *\end{array}$ \\
\hline Brazil & $\begin{array}{c}\text { ARMA } \\
(1,0)\end{array}$ & $\begin{array}{l}0.00 \\
* * *\end{array}$ & $\begin{array}{l}0.92 \\
* * *\end{array}$ & & & & & & & & & $\begin{array}{l}-0.11 \\
* * *\end{array}$ & $\begin{array}{l}-0.48 \\
* * *\end{array}$ & $\begin{array}{l}0.99 \\
* * *\end{array}$ & $\begin{array}{l}0.30 \\
* * * *\end{array}$ & $\begin{array}{l}3.23 \\
* * *\end{array}$ \\
\hline India & $\begin{array}{c}\text { ARMA } \\
(3,0)\end{array}$ & $\begin{array}{l}0.00 \\
* * *\end{array}$ & $\begin{array}{l}0.76 \\
* * * *\end{array}$ & 0.14 & 0.12 & & & & & & & $\begin{array}{l}-1.14 \\
* * *\end{array}$ & $\begin{array}{c}-0.24 \\
*\end{array}$ & $\begin{array}{l}0.92 \\
* * *\end{array}$ & $\begin{array}{l}0.79 \\
* * *\end{array}$ & $\begin{array}{l}2.54 \\
* * *\end{array}$ \\
\hline Mexico & $\begin{array}{c}\text { ARMA } \\
(2,0)\end{array}$ & $\begin{array}{l}0.00 \\
* * *\end{array}$ & $\begin{array}{l}0.75 \\
* * *\end{array}$ & $\begin{array}{l}0.10 \\
* * *\end{array}$ & 0.12 & & & & & & & $\begin{array}{l}-2.25 \\
* *\end{array}$ & -0.24 & $\begin{array}{l}0.81 \\
* * *\end{array}$ & $\begin{array}{c}0.80 \\
*\end{array}$ & $\begin{array}{l}2.16 \\
* * *\end{array}$ \\
\hline Peru & $\begin{array}{c}\text { ARMA } \\
(4,0)\end{array}$ & $\begin{array}{l}0.00 \\
* * *\end{array}$ & $\begin{array}{l}-0.06 \\
* * *\end{array}$ & $\begin{array}{l}0.31 \\
* * *\end{array}$ & $\begin{array}{l}0.45 \\
* * *\end{array}$ & $\begin{array}{l}0.32 \\
* * *\end{array}$ & & & & & & $\begin{array}{l}-0.42 \\
* * *\end{array}$ & $\begin{array}{l}0.02 \\
* * *\end{array}$ & $\begin{array}{l}0.97 \\
* * *\end{array}$ & $\begin{array}{l}0.95 \\
* * * *\end{array}$ & $\begin{array}{l}3.07 \\
* * *\end{array}$ \\
\hline Russia & $\begin{array}{c}\text { ARMA } \\
(3,1)\end{array}$ & $\begin{array}{l}0.01 \\
* * *\end{array}$ & $\begin{array}{l}0.09 \\
* * *\end{array}$ & $\begin{array}{l}0.84 \\
* * *\end{array}$ & $\begin{array}{l}0.08 \\
* * *\end{array}$ & & & $\begin{array}{l}0.89 \\
* * *\end{array}$ & & & & -0.02 & -0.12 & $\begin{array}{l}0.99 \\
* * *\end{array}$ & $\begin{array}{l}0.24 \\
* * *\end{array}$ & $\begin{array}{l}4.40 \\
* * *\end{array}$ \\
\hline Indonesia & $\begin{array}{c}\text { ARMA } \\
(1,2)\end{array}$ & $\begin{array}{l}0.01 \\
* * *\end{array}$ & $\begin{array}{l}0.99 \\
* * *\end{array}$ & & & & & $\begin{array}{l}-0.36 \\
* * *\end{array}$ & -0.08 & & & -1.55 & 0.04 & $\begin{array}{l}0.88 \\
* * *\end{array}$ & $\begin{array}{l}0.44 \\
* * *\end{array}$ & $\begin{array}{l}3.84 \\
* * *\end{array}$ \\
\hline UK & $\begin{array}{c}\text { ARMA } \\
(2,1)\end{array}$ & 0.00 & $\begin{array}{l}1.22 \\
* * *\end{array}$ & $\begin{array}{l}-0.27 \\
* * *\end{array}$ & & & & $\begin{array}{l}-0.70 \\
* * *\end{array}$ & & & & -0.06 & $\begin{array}{l}-0.32 \\
* * *\end{array}$ & $\begin{array}{l}0.99 \\
* * *\end{array}$ & $\begin{array}{l}0.74 \\
* * *\end{array}$ & $\begin{array}{l}4.90 \\
* * *\end{array}$ \\
\hline Italy & $\begin{array}{c}\text { ARMA } \\
(4,0)\end{array}$ & $\begin{array}{l}0.00 \\
* * *\end{array}$ & $\begin{array}{l}0.99 \\
* * *\end{array}$ & & & & & $\begin{array}{l}-0.38 \\
* * *\end{array}$ & -0.08 & & & $\begin{array}{l}-0.28 \\
* * *\end{array}$ & $\begin{array}{l}0.14 \\
* * *\end{array}$ & $\begin{array}{l}0.98 \\
* * *\end{array}$ & $\begin{array}{l}0.11 \\
* * * *\end{array}$ & $\begin{array}{c}76.78 \\
* * *\end{array}$ \\
\hline Colombia & $\begin{array}{c}\text { ARMA } \\
(2,0)\end{array}$ & $\begin{array}{l}0.01 \\
* * * *\end{array}$ & $\begin{array}{l}0.90 \\
* * * *\end{array}$ & $\begin{array}{l}0.10 \\
* * *\end{array}$ & & & & & & & & $\begin{array}{l}-2.95 \\
* * *\end{array}$ & -0.00 & $\begin{array}{l}0.81 \\
* * *\end{array}$ & $\begin{array}{l}0.98 \\
* * *\end{array}$ & $\begin{array}{l}2.84 \\
* * *\end{array}$ \\
\hline Iran & $\begin{array}{c}\text { ARMA } \\
(1,2)\end{array}$ & $\begin{array}{l}0.00 \\
* * *\end{array}$ & $\begin{array}{l}0.98 \\
* * *\end{array}$ & & & & & $\begin{array}{l}-0.38 \\
* * *\end{array}$ & -0.08 & & & $\begin{array}{l}-0.28 \\
* * *\end{array}$ & $\begin{array}{l}0.14 \\
* * *\end{array}$ & $\begin{array}{l}0.98 \\
* * *\end{array}$ & $\begin{array}{l}0.11 \\
* * *\end{array}$ & $\begin{array}{c}76.78 \\
* * *\end{array}$ \\
\hline France & $\begin{array}{c}\text { ARMA } \\
(5,0)\end{array}$ & $\begin{array}{l}0.00 \\
* * *\end{array}$ & $\begin{array}{l}0.48 \\
* * *\end{array}$ & $\begin{array}{c}-0.13 \\
* * *\end{array}$ & $\begin{array}{l}0.41 \\
* * *\end{array}$ & $\begin{array}{l}0.29 \\
* * *\end{array}$ & $\begin{array}{l}-0.06 \\
* * *\end{array}$ & & & & & $\begin{array}{l}-0.17 \\
* * *\end{array}$ & $\begin{array}{l}0.39 \\
* * *\end{array}$ & $\begin{array}{l}0.99 \\
* * *\end{array}$ & $\begin{array}{c}-0.14 \\
* * *\end{array}$ & $\begin{array}{l}4.80 \\
* * *\end{array}$ \\
\hline Argentina & $\begin{array}{c}\text { ARMA } \\
(4,0)\end{array}$ & $\begin{array}{l}0.00 \\
* * *\end{array}$ & $\begin{array}{l}0.99 \\
* * *\end{array}$ & & & & & $\begin{array}{l}-0.82 \\
* * *\end{array}$ & & & & $\begin{array}{l}-0.26 \\
* * *\end{array}$ & $\begin{array}{l}0.12 \\
* * *\end{array}$ & $\begin{array}{l}0.98 \\
* * *\end{array}$ & $\begin{array}{l}-0.09 \\
* * *\end{array}$ & $\begin{array}{l}7.85 \\
* * *\end{array}$ \\
\hline Germany & $\begin{array}{c}\text { ARMA } \\
(1,3)\end{array}$ & $\begin{array}{l}0.00 \\
* * *\end{array}$ & $\begin{array}{l}0.59 \\
* * *\end{array}$ & & & & & $\begin{array}{l}0.17 \\
* * *\end{array}$ & 0.21 & $\begin{array}{l}0.18 \\
* * *\end{array}$ & & $\begin{array}{c}-0.09 \\
* * *\end{array}$ & 0.09 & $\begin{array}{l}0.99 \\
* * *\end{array}$ & $\begin{array}{l}0.42 \\
* * *\end{array}$ & $\begin{array}{l}2.34 \\
* * *\end{array}$ \\
\hline Spain & $\begin{array}{c}\text { ARMA } \\
(5,2)\end{array}$ & $\begin{array}{l}0.00 \\
* * *\end{array}$ & $\begin{array}{l}1.53 \\
* * *\end{array}$ & $\begin{array}{l}-1.27 \\
* * *\end{array}$ & $\begin{array}{l}0.75 \\
* * *\end{array}$ & $\begin{array}{c}-0.57 \\
* * *\end{array}$ & $\begin{array}{l}0.48 \\
* * * *\end{array}$ & $\begin{array}{l}-1.21 \\
* * * \\
\end{array}$ & $\begin{array}{l}0.72 \\
* * *\end{array}$ & -0.20 & & -0.20 & $\begin{array}{c}-0.25 \\
* *\end{array}$ & $\begin{array}{l}0.99 \\
* * *\end{array}$ & $\begin{array}{l}0.75 \\
* * * *\end{array}$ & $\begin{array}{l}5.44 \\
* * *\end{array}$ \\
\hline
\end{tabular}

\section{Copyrights}

Copyright for this article is retained by the author(s), with first publication rights granted to the journal.

This is an open-access article distributed under the terms and conditions of the Creative Commons Attribution license (http://creativecommons.org/licenses/by/4.0/). 